\title{
Toxoplasma gondii Induces Death of Gastric Myenteric Neurons in Rats
}

\author{
Toxoplasma gondii Induce la Muerte de Neuronas del Plexo Mientérico Gástrico en Ratas
}

\author{
Marcelo Sardeto Alves; Aristeu Vieira da Silva; Larissa Renata de Oliveira Bianchi; \\ Eduardo José de Almeida Araújo \& Débora de Mello Gonçales Sant’Ana
}

ALVES, M. S.; SILVA, A. V.; BIANCHI, L. R. O.; ARAÚJO, E. J. A. \& SANT'ANA, D. M. G. Toxoplasma gondii induces death of gastric myenteric neurons in rats. Int. J. Morphol., 29(1):293-298, 2011.

SUMMARY: The aim of the study was quantifying and morphologically analyzing the myenteric neurons of the small and large gastric curvatures of the glandular stomach of rats infected the tachyzoites of the Toxoplasma gondii for 30 days. Ten male rats were assigned into two groups: Control Group (CG) and Experimental Group (EG). The animals from the CG received saline solution orally whereas the EG animals received 104 tachyzoites of the $T$. gondii genotype III strain (BTU II). After 30 days, euthanasia was conducted for the removal of the stomach, which was dissected under the stereomicroscope for removal of the tunica mucosa and the tela submucosa. Whole mounts were stained with Giemsa. Quantification of the myenteric neurons was conducted by using a 40X-objective microscope in 40 microscopic fields for the region of the small gastric curvature and 40 fields for the large gastric curvature of the glandular stomach of the animals from both groups. The cell body of 50 myenteric neurons from each region was measured for each animal. Chronic experimental infection caused by the genotype III strain of Toxoplasma gondii was verified to reduce myenteric neuron density only in the small gastric curvature region of the glandular stomach, not resulting in significant changes in the size of the neurons.

KEY WORDS: Stomach; Toxoplasmosis; Enteric nervous system; Myenteric plexus.

\section{INTRODUCTION}

Gastric lesions caused by T. gondii are described for humans and animals (Alpert et al., 1996; Schreiner \& Liesenfeld, 2009). In immunodepressed humans, they involve ulceration, thickening of gastric wall and folds, thickening and necrosis of tunica mucosa and inflammatory infiltrates (Alpert et al.; Kofman et al., 1996; Smart et al., 1990). Several animals species also present inflammatory infiltrates and necrosis on the gastric wall after infection with T. gondii (Canfield et al., 1990; Cunningham et al., 1992; Hartley et al., 1990; Inskeep et al., 1990; Schreiner \& Liesenfeld).

Studies on experimental gastric toxoplasmosis are rare. Stoicov et al. (2004) infected BALB/c mice with $T$. gondii for 20 weeks and occasionally verified tachyzoites on the gastric mucosa, even though they induced no alterations on its structure, causing little inflammation and maintaining the gastric wall thickness.
Confirming gastric toxoplasmosis can be performed by demonstrating the presence of tachyzoites and cysts of $T$. gondii by histopathologic methods, immunohistochemical and ultrastructural (Alpert et al.; Kofman et al.; Smart et $a l$.). The parasite was found inside the epithelial, muscle and endothelial cells, macrophages (Alpert et al.) and inside intracellular vacuoles in glandular cells on the gastric wall (Florêncio et al., 1992).

The presence of gastric changes indicates that the stomach myenteric plexus is subjected to direct and indirect lesions by $T$. gondii and the lack of reports with respect to the myenteric plexus of these organs led us to propose this study. The aim of this study was quantifying and morphologically analyzing the myenteric neurons of the small and large gastric curvatures of the glandular stomach of rats infected the tachyzoites from this parasite for 30 days. 


\section{MATERIAL AND METHOD}

All experimental procedures were previously approved by the Ethics Committee Involving Animal Experimentation Research of the Universidade Paranaense (Protocol n¹2361).

Ten sixty-day-old male Wistar rats were assigned into two groups: Control Group (CG) and Experimental Group (EG). The animals from the $\mathrm{CG}$ received $0.9 \%$ saline solution orally whereas the EG animals orally received 104 tachyzoites from a T. gondii strain (BTU II) isolated from dogs with neurologic symptomatology, classified as genotype III through the analysis of the SAG-2 gene (Da Silva et al., 2005; Sevá et al., 2006). Tachyzoites were from the Laboratory of Preventive Veterinary Medicine and Public Health of Universidade Paranaense. The animals were kept in individual cages and received water and chow ad libitum for 30 days (enough time to cause chronic infection in rats), and then anesthesized intramuscularly with Acepram $1.26 \mathrm{~mL} / \mathrm{kg}+$ Ketamine $(10 \mathrm{~mL}) 1.26 \mathrm{~mL} / \mathrm{kg}+$ Xylazine $(2 \%)$ $0.42 \mathrm{~mL} / \mathrm{kg}+$ Atropine $(1 \%) 0.22 \mathrm{~mL} / \mathrm{kg}$, according to the protocol of Pachaly et al. (2003).

Blood was collected prior to euthanasia, under anesthesia, from the animals through punction of the retroorbital venous plexus of each animal, both groups, in order to detect anti- $T$. gondii seric antibodies by direct agglutination (Da Silva et al., 2002).

Vertical laparotomy was conducted in all of the animals for the removal of the stomach, which was weighed, decaled, and had its area measured with Motic Images Plus $2.0 ®$. The small and large curvatures of the glandular portion of each organ were used in this experiment.

The glandular stomach of all animals was fixed in acetic formol and then dissected under a stereomicroscope (DMI Motic SMZ-140) for the removal of the tunica mucosa and the tela submucosa. Whole mounts were stained with methylene blue according to Giemsa technique (Barbosa, 1978).

Quantification of myenteric neurons was carried out by using an optical microscope (Motic B1). The total number of myenteric neurons in 40 fields (magnified 400X) of the small gastric curvature and 40 fields of the lesser curvature of the glandular stomach of each animals from the CG and EG was counted. The area of the microscopic field was $0.224 \mathrm{~mm}^{2}$.

Besides, the cell body of 50 myenteric neurons from each area studied per animal was measured. Images captured with a digital camera (MOTICAM 2000) attached to a trinocular light microscope (Motic B5) and image analyzer software (Motic Image Plus 2.0).

Data collected were submitted to KolmogorovSmirnov test to verify the distribution type. Data with normal distribution are presented as mean and standard deviation and were compared by Student's t-test for independent samples. Data with free distribution are presented as median and percentile (P25;P75) and were compared by MannWhitney test. $\mathrm{P}$ values lower than 0.05 were considered significant for all statistical tests.

\section{RESULTS}

In this study, the animals presented no clinical sign of toxoplasmosis. Neither lesion points nor hemorrhage were macroscopically detected on the stomachs.

Through the serologic exam, the EG animals had positive result for the presence of anti-T. gondii antibodies, whereas the CG ones had negative results. EG animals presented $14.73 \%$ decrease in their stomach mean weight $(1.39$ $\pm 0.07 \mathrm{~g})$ when compared to the $\mathrm{CG}(1.63 \pm 0.02 \mathrm{~g})(\mathrm{p}=0.001)$. a $17.12 \%$ decrease of the mean stomach area between the CG $\left(7.01 \pm 1.05 \mathrm{~cm}^{2}\right)$ and the EG $\left(5.81 \pm 1.51 \mathrm{~cm}^{2}\right)$ was observed, but the difference was not significant $(\mathrm{p}=0.091)$.

Table I. Population density in area $8.96 \mathrm{~mm}^{2}$ and the cell body of myenteric neurons of the glandular stomach of healthy rats (Control Group - CG) and subjected to infection with a genotype III strain of T. gondii (Experimental Group - EG). The number of neurons are presented as mean and standard deviation. The area of the cell body is presented as median and percentiles 25 and 75 . Values followed by same letters in the same column, significant difference $\mathrm{p}<0.05$.

\begin{tabular}{lccc}
\hline Region & Group & Neurons number & Area of the cell body $\left(\boldsymbol{\mu m ^ { 2 }}\right)$ \\
\hline Greater gastric curvature & CG & $2.495^{\mathrm{a}} \pm 91.6$ & $334(264.4 ; 389.5)$ \\
& EG & $1.865^{\mathrm{c}} \pm 221.4$ & $300(246.7 ; 390.7)$ \\
Lesser gastric curvature & CG & $3.248^{\mathrm{ab}} \pm 135.9$ & $236(165.7 ; 308.0)$ \\
& EG & $2.353^{\mathrm{b}} \pm 45.0$ & $251(139.0 ; 340.0)$
\end{tabular}


No form of life of $T$. gondii was observed inside the neurons. When compared, the population density of myenteric neurons of the small gastric curvature of the stomach of the CG and EG animals, it was possible to verify significant difference $(\mathrm{p}=0.012)$, as demonstrated in Table I. The small gastric curvature region of the glandular stomach presented $27.56 \%$ decrease of population density of myenteric neurons, whereas the large gastric curvature region from the same stomach portion presented $25.25 \%$ decrease of myenteric neurons.

Neuronal measurement presented no significant difference with respect to the gastric curvature between the groups (Table I).

\section{DISCUSSION}

Although Toxoplasma gondii tachyzoites present sensibility to the gastric juice (Dubey, 1998; Montoya \& Remington, 2000), it was possible to verify the effectivity of the infection by $T$. gondii by means of evidencing the production of anti-T. gondii seric antibodies. Tachyzoites from the genotype III strain of $T$. gondii were capable of resisting the gastric juice and cross the gastrointestinal tract barrier, reaching the systemic circulation, resulting in the formation of circulating antibodies. However, the infection presented, despite causing no deaths throughout the study, can be considered subclinical in its chronic stage, as no perceivable signs of the disease were observed. According to De Champs et al. (1998), there is little literature on evidences of the clinical disease in rats, causing the infection to be considered asymptomatic for these animals.

This protozoan presents three distinct clonal lineages: I, II, III (Howe \& Sibley, 1995). It is know that strains from the same genotype can have distinct behavior depending on the region (Fuentes et al., 2001; Sevá et al.). For mice, genotype III strains isolated in Brazil are considered highly virulent (Da Silva et al., 2005; Dubey et al., 2002; Sevá et $a l$.), contrary to what is reported in the Northern Hemisphere in which it is considered low virulent for the same species (Howe \& Sibley). In this study with rats, the genotype III strain was used - enabling the development of chronic infection in the animals, not resulting in the development of clinical signs. Despite the lack of clinical signs, decrease of the stomach area and weight were observed. Studies involving the same animals demonstrated decrease of the jejunal and ileal area, resulting in atrophy or hypoplasia of the organ, possibly mediated by the tissue cytokines secreted due to the presence of the parasite (Sugauara et al., 2008; Torres, 2009).
All clonal genotypes are able to form cysts on the nervous tissue (Fagard et al., 1999). Dubey (1997), describes that in rodents apart from the strain of $T$. gondii, the formation of tissue cysts occurs mainly in the brain, and can also be found in the intestine and other organs, as after inoculation they can take around 10 (Sevá et al.) to 15 days to constitute themselves (Dubey, 1997; Holst \& Chinchilla, 1990). In the neurons of the myenteric plexus evaluated no tissue cysts of $T$. gondii were found, which concurs with tht stated in the literature which highlights the difficulty to find them as they are diffusively and heterogeneously formed, considering all the organism (Montoya \& Remington).

Despite the lack of cysts inside the enteric neurons, the myenteric plexus has been described as a tissue subject to changes induced by the infection with T. gondii (Bonapaz, 2009; Odorizzi, 2009; Papazian-Cabañas, 2008; Soares et al., 2009; Sugauara et al., 2008, 2009; Torres).

With respect to the neuronal population density in this study, significant decrease of the number of myenteric neurons were observed only for the small gastric curvature region of the glandular stomach of the animals infected with T. gondii. It is believed that the neurons in this small gastric curvature region are more vulnerable to the direct and indirect effects of the infection, as this region is the entrance to the organ. Decrease of the myenteric neuron population in the duodenum of birds infected with oocysts of a genotype III strain of $T$. gondii was also described by Bonapaz.

Contrary to the result found for the small gastric curvature, no significant change in the neuronal density between the groups was observed for the large gastric curvature of the glandular stomach. This finding is similar to that found for other segments of the intestine of rats infected with T. gondii, such as: duodenum (Papazian-Cabañas), terminal ileum, descending colon (Soares et al.; Sugauara et al., 2008; Sugauara et al., 2009).

Differences regarding the myenteric neuron population in different regions of rat stomach are evidenced by authors observing higher population density for the small gastric curvature, where the muscle tunic is thicker (Fregonesi et al., 2004; Safrey \& Burnstock, 1994). However, in those studies, the total neuronal populations, except for the subpopulations, were not evaluated. In this study, methylene blue, a pan-neuronal marker (Sant'Ana et al., 1997), was used and results similar to the evaluations of the neuronal subpopulation were observed, that is, higher concentration of neurons in the small gastric curvature. Due to differences in the myenteric neuron population distribution, according to the thickness of the smooth muscle layer, it is necessary that the evaluation of each digestive tract region occurs, even in 
the organ itself, so that no interpretative error impairs the research result (Miranda-Neto et al., 2001).

Sugauara et al. $(2008,2009)$ and Odorizzi suggest that the infection with $T$. gondii causes changes on the myenteric neurons indirectly, more precisely, by an action of the immune response. One of the cytokines involved in the inflammatory response, the IFN-gama, plays a key role on the resistance against the infection with $T$. gondii (Suzuki et al., 1988), being necessary to the efficient activation of the macrophages (Deckert-Schluter et al., 1996 ; Sibley et al., 1993). In turn, the cytokines IL-1b and TNF-a rise at the initial inflammatory process increasing the secretion of prostaglandins and leukotrienes, thus contributing to the increase of the tissue inflammation, interfering on the functioning of the smooth musculature of the gastrointestinal tract (Shea-Donohue et al., 1997). Mediators IFN-gama and nitric oxide involved in infections by protozoans may induce morphological and quantitative changes in myenteric neurons (Arantes et al., 2004). This leads us to infer that the number of tachyzoites on the small gastric curvature was higher than on the rest of the organ and consequently triggered a more expressive inflammatory response in that region, resulting in the decrease of its neuronal population.

No significant changes with respect to the frequency of neurons on the glandular stomach of rats among the class intervals of the cell body area, as well as when compared the cellular measurement between the groups, which means that the neurons that survived the period of infection presented no significant changes in their cellular structure. Studies conducted in other segments of the digestive tube of the same animals in this study presented distinct results. Neuronal hypertrophy (Papazian-Cabañas; Sugauara et al., 2008) occurred on the duodenum and the descending colon, whereas nucleus (Torres) and cell (Sugauara et al., 2008), area decrease occurred for the jejunum and ileum, respectively, demonstrating that the response of the myenteric plexus was distinct in the organ studied.

The lack of other studies describing the effects of the infection with $T$. gondii on the stomach myenteric plexus prevent us from comparing the current results directly and leads us to identify the need for additional studies revealing which myenteric neuron subpopulations are more susceptible to lesion and death because of the infection. Also, immunohistochemical and ultra-structural studies will clarify possible cytoplasmatic changes and the mechanisms involved in neuronal death.

Through this explanatory study, chronic experimental infection caused by Toxoplasma gondii (genotype III strain) in rats was observed to reduce myenteric neuron density in the small gastric curvature region of the glandular stomach. Moreover, the neurons which survived the infection presented no significant plastic changes in the cell body.

ALVES, M. S.; SILVA, A. V.; BIANCHI, L. R. O.; ARAÚJO, E. J. A. \& SANT'ANA, D. M. G. Toxoplasma gondii induce la muerte de neuronas del plexo mientérico gástrico. Int. J. Morphol., 29(1):293-298, 2011.

RESUMEN: Este estudio tuvo como objetivos cuantificar y analizar morfológicamente neuronas del plexo mientérico de las curvaturas gástricas menor y mayor del estómago glandular de ratones infectados durante 30 días por taquizoítos de Toxoplasma gondii. Fueron utilizados 10 ratas machos distribuidos aleatoriamente en dos grupos: grupo control (GC) y grupo experimental (GE). Los animales del GC recibieron solución salina por vía oral y los animales del GE recibieron, por la misma vía, 104 taquizoítos de Toxoplasma gondii de una cepa genotipo III (cepa BTU II). Tras 30 días, se realizó eutanasia para retirar el estómago, que fue disecado bajo el estereomicroscopio para retirar la túnica mucosa y tela submucosa. Preparados de membrana fueron coloreados por la técnica de Giemsa. La cuantificación de neuronas mientéricas se realizó con microscopía óptica, con objetivo de $40 \mathrm{X}$ en 40 campos microscópicos para la región de la curvatura gástrica menor y 40 campos para la curvatura gástrica mayor del estómago glandular, en ambos grupos. Se midió el área del cuerpo celular de 50 neuronas mientéricas de cada región en cada animal. Se verificó que la infección experimental crónica provocada por la cepa de genotipo III de Toxoplasma gondii en ratones, redujo la densidad de neuronas mientéricas solamente en la región de curvatura gástrica menor del estómago glandular, no llevando a alteraciones significativas el tamaño de las neuronas.

PALABRAS CLAVE: Estómago; Toxoplasmosis; Sistema nervioso entérico; Plexo mientérico.

\section{REFERENCES}

Alpert, L.; Miller, M.; Alpert, E.; Satin, R.; Lamoureux, E. \& Trudel, L. Gastric Toxoplasmosis in Acquired Immunodeficiency Syndrome: Antemortem diagnosis with histopathologic characterization. Gastroenterology, 110:258-64, 1996.
Arantes, R. M. E.; Marche, H. H. F.; Bahia, M. T.; Cunha, F. Q.; Rossi, M. A. \& Silva, J. S. Interferon-g-Induced Nitric Oxide Causes Intrinsic Intestinal Denervation in Trypanosoma cruzi- Infected Mice. AJP, 164:1361-8, 2004. 
Barbosa, A. J. A. Técnica histológica para gânglios nervosos intramurais em preparados espessos. Braz. J. Med. Biol. Res., 11:95-7, 1978.

Bonapaz, R. S. Efeitos da infecção por oocistos de Toxoplasma gondii sobre a parede intestinal e o plexo mientérico de Gallus gallus [Dissertation]. Umuarama (PR), Universidade Paranaense, 2009.

Canfield, P. J.; Hartley, W. J. \& Dubey, J. P. Lesions of Toxoplasmosis in Australian Marsupials. J. Comp. Path., 103:159-67, 1990.

Cunningham, A. A.; Bruxton, D. \& Thomson, K. M. An epidemic of toxoplasmosis in a captive colony of squirrel monkeys (Saimiri sciureus). J. Comp. Pathol., 107:20719, 1992.

Da Silva, A. V.; Cutolo, A. A. \& Langoni, H. Comparação da reação de imunofluorescência indireta e do método de aglutinação direta na detecção de anticorpos antiToxoplasma em soros de ovinos, caprinos, caninos, e felinos. Arq. Inst. Biol., 69:7-11, 2002.

Da Silva, A. V.; Pezerico, S. B.; de Lima, V. Y.; d'Arc Moretti, L.; Pinheiro, J. P.; Tanaka, E. M.; et al. Genotyping of Toxoplasma gondii strains isolated from dogs with neurologicas signs. Vet. Parasitol., 127:23-7, 2005.

De Champs, C.; Pelloux, H.; Dechelotte, P.; Giraud, J. C.; Bally, N. \& Ambroise-Thomas, P. Toxoplasma gondii infection in rats by the RH strain: inoculum and age effects. J. Parasitol., 5:215-8, 1998.

Deckert-Schluter, M.; Rang, A.; Weiner, D.; Huang, S.; Wiestler, O. D.; Hof H.; et al. Interferon-gamma receptor-deficiency renders mice highly susceptible to toxoplasmosis by decreased marcophage activation. Lab. Invest. Gainesville., 75:827-41, 1996.

Dubey, J. P. Distribution of tissue cysts in organs of rats fed Toxoplasma gondii oocysts. J. Parasitol., 83:755-7, 1997.

Dubey, J. P. Structures of Toxoplasma gondii tachyzoites, bradyzoites, and sporozoites and biology and development of tissue cysts. Clin. Microbiol. Rev., 11:294, 1998.

Dubey, J. P.; Graham, D. H.; Blasckston, C. R.; Lehmann, T.; Genari, S. M.; Ragozo, A. M. A.; et al. Biological and genetic characterization of Toxoplasma gondii isolates from chickens (Gallus domesticus) from São Paulo, Brazil: unexpected findings. Int. J. Parasitol., 32:99-105, 2002.
Fagard, R.; Van Tan, H.; Creuzet, C. \& Pelloux, H. Differential Development of Toxoplasma gondii in Neural Cells. Parasitol. Today, 15:504-7, 1999.

Florêncio, F. R. C.; Filho, F. B. A. \& Moraes, M. A. P. Toxoplasma gondii na mucosa gástrica como primeiro achado em paciente aidético. Rev. Soc. Bras. Med. Trop., 25:275-6, 1992 .

Fregonesi, C. E. P. T.; Molinari, S. L. \& Miranda-Neto, M. H. Avaliação da população de neurônios mioentéricos NADPH-diaforase positivos do corpo do estômago de ratos com diabetes crônico induzido pela estreeptozootocina. Acta Scientiarum, 26:107-12, 2004.

Fuentes, I.; Rubio, J. M.; Ramirez, C. \& Alvar, J. Genotypic characterization of Toxoplasma gondii strains associated with human toxoplasmosis in Spain: direct analysis from clinical samples. J. Clin. Microbiol., 39:1566-70, 2001.

Hartley, W. J., Dubey, J. P. \& Spielman, D. S. Fatal toxoplasmosis in Koalas (Phascoalarctos cinereus). $J$. Parasitol., 76:271-2, 1990.

Holst, I. \& Chinchilla, M. Development and distribution of cysts of an avirulent strain of Toxoplasma and the humoral immune response in mice. Rev. Biol. Trop., 38:18993, 1990.

Howe, D. K. \& Sibley, L. D. Toxoplasma gondii comprises three clonal lineages: correlation of parasite genotype with human disease. JID, 172:1561-6, 1995.

Inskeep, W.; Gardiner, C. H.; Harris, R. K.; Dubey, J. P. \& Goldston, R. T. Toxoplasmosis in Atlantic Bottle-Nosed Dolphins (Tursiops truncatus). J. Wildl. Dis., 26:37782, 1990 .

Kofman, E.; Khorsandi, A.; Sarlin, J. \& Adhami, K. Gastric Toxoplasmosis: case report and review of the literature. AJG, 91:2436-8, 1996.

Miranda-Neto, M. H.; Molinari, S. L.; Natali, M. R. M. \& Sant'Ana, D. M. G. Regional differences in the number and type of myenteric neurons of the ileum of rats: a comparison of techniques of neuronal evidentiation. Arq. Neuropsiquiatr., 59:54-9, 2001.

Montoya, J. G. \& Remington, J. S. Toxoplasma gondii. 2000. Retraction in: Mandel, G. L.; Bennett, J. E. \& Dolin, R. (Eds.). Principles and pratice of infections diseases. 5a Ed. Philadelphia, Livingstone, 2000. pp.2858-85. 
ALVES, M. S.; SILVA, A. V.; BIANCHI, L. R. O.; ARAÚJO, E. J. A. \& SANT'ANA, D. M. G. Toxoplasma gondii induces death of gastric myenteric neurons in rats. Int. J. Morphol., 29(1):293-298, 2011.

Odorizzi, L. Hipertrofia de neurônios mientéricos nitrérgicos de suínos com Toxoplasmose [Dissertation]. Umuarama (PR), Universidade Paranaense, 2009.

Pachaly, J. R.; Sant'Ana, D. M. G.; Araújo, E. J. A.; Ciffoni, E. M. C. \& Acco, A. Anesthesia of wistar rats (Rattus norvegicus) with allometrically scaled doses of ketamine, xylazine, acepromazine and atropine-prelimanary report. Arq. Cienc. Vet. Zool., 6:195, 2003.

Papazian-Cabañas, R. M. Plasticidade neuronal mientérica induzida pelo Toxoplasma gondii (GENÓTIPO III) no duodeno de ratos. [Work of Completion]. Umuarama, Universidade Paranaense, 2008.

Safrey, M. J. \& Burnstock, G. Grourthfactors and the developments and plasticity of the enteric nervous system. J. Autom. Ner. Syst., 49:183-96, 1994.

Sant'Ana, D. M. G.; Miranda-Neto, M. H.; Molinari, S. L. \& Sant'Ana, M. A. Neuron number in the myenteric plexus of the ascending colon of rats. Arq. Neuropsiquiatr., 55:460-6, 1997.

Schreiner, M. \& Liesenfeld, O. Small intestinal inflammation following oral infection with Toxoplasma gondii does not occur exclusively in C57BL/6 mice: review of 70 reports from the literature. Mem. Inst. Oswaldo Cruz, 104:221-33, 2009.

Sevá, A. P.; Silva, R. C.; Silva, A. V.; Castro, A. P. B.; Menozzi, B. D. \& Langoni, H. Avaliação da virulência de cepas de Toxoplasma gondii, em camundongos, isoladas de cães com sinais neurológicos, em Botucatu, SP. Vet e Zootec., 13:33-43, 2006.

Shea-Donohue, T.; Goldhill, J. M.; Montcalm-Mazzilli, E.; Colleton, C.; Pineiro-Carrero, V. M. \& Sjogren, R. W. Role of sensory afferents in the myoelectric response to acute enteric inflammation in the rabbit. Am. J. Physiol. Bethesda., 273:447-55, 1997.

Sibley, L. D., Adams, L. B. \& Krahenbuhl, J. L. Macrophage interactions in toxoplasmosis. Res. Immunol., 144:3840, 1993.

Smart, P. E.; Weinfeld, A.; Thompson, N. E. \& Defortuna, S. M. Toxoplasmosis of the stomach: A cause of antral narrowing. Radiology, 174:369-70, 1990.

Soares, J.; Moreira, N. M.; Silva, A. V.; Sant'Ana, D. M. G. \& Araújo, E. J. A. Infecção crônica por Toxoplasma gondii induzindo hipertrofia de neurônios do plexo mientérico do cólon descendente de Rattus norvegicus. Rev. Bras. Parasitol. Vet., 18:57-60, 2009.

Stoicov, C.; Whary, M.; Rogers, A. B.; Lee, F. S.; Klucevsek, K.; Li, H., et al. Coinfection modulates inflammatory responses and clinical outcome of Helicobater felis and Toxoplasma gondii infections. J. Immunol., 3329:3336, 2004.

Sugauara, E. Y. Y.; Sant'Ana, D. M. G.; Almeida, E. C.; Reis, A. B.; Silva, A. V. \& Araújo, E. J. A. Alterations of the myenteric plexus of the ileum and the descending colon caused by Toxoplasma gondii (Genotype III). Arq. Neuropsiquiatr., 66:516-23, 2008.

Sugauara, E. Y. Y.; Sant'Ana, D. M. G.; Silva, A. V.; Souza, E. A. \& Araújo, E. J. A. Hypertrophy of the neurons in the ileum of rats infected with cysts of Toxoplasma gondii (genotype II). Acta Scientiarum., 31:195-201, 2009.

Suzuki, Y.; Orellana, M. A.; Schreiber, R. D. \& Remington, J. S. Interferon-gama: the major mediator of resistance agaist Toxoplasma gondii. Science, 240:516-8, 1988.

Torres, J. R. P. Plasticidade neuronal mientérica no jejuno de ratos submetidos à infecção aguda e crônica por cepa brasileira virulenta do tipo III de Toxoplasma gondii [Dissertation]. Umuarama (PR), Universidade Paranaense, 2009.

Correspondence to:

Débora de Mello Gonçales Sant'Ana

Laboratório de Neurogastroenterologia Experimental Universidade Paranaense

Praça Mascarenhas de Moraes, 4282 Centro

Zip Code 87506-140

Umuarama - PR

BRAZIL

Email: debora@unipar.br

Received: 27-08-2010

Accepted: 22-11-2010 